\title{
Maskuliniti yang Diruntuhkan Feminiti: Satu Penelitian Stereotaip Gender dalam Novel Seri Dewi Malam Karya Affifudin Haji Omar
}

\author{
WAN HASMAH WAN TEH \\ Bahagian Kesusasteraan, Pusat Pengajian Ilmu Kemanusiaan, Universiti Sains Malaysia, \\ 11800 Pulau Pinang, Malaysia. \\ hasmahwt@usm.my
}

\begin{abstract}
Abstrak Ideologi feminis menyumbang kepada fahaman bahawa lelaki dan perempuan dipengaruhi oleh pengalaman kehidupan yang berbeza ketika menghasilkan sesebuah karya kreatif. Feminis percaya bahawa pengarang lelaki tidak dapat menampilkan dimensi kejiwaan perempuan kerana mereka tidak pernah merasai pengalaman sebagai seorang perempuan. Ideologi seperti ini muncul sebagai tindak balas terhadap kebanyakan karya yang dihasilkan oleh pengarang lelaki yang sering mempersembahkan watak perempuan sebagai the second sex, terpinggir, bisu dan lemah dalam sistem sosial yang didominasi oleh lelaki. Walau bagaimanapun, tindakan pengarang lelaki ini tidak boleh dihukum kerana kegagalan mereka memahami dimensi perempuan yang berbeza dari diri mereka. Pencitraan perempuan daripada perspektif pengarang lelaki harus dilihat daripada konteks masyarakat dan budaya yang meletakkan stereotaip tertentu mengikut jenis kelamin. Bertitik tolak daripada fahaman tersebut, makalah ini mengupas konsep gender yang dibentuk oleh masyarakat sosial serta meneliti imej stereotaip lelaki yang dikenali sebagai gender maskulin dan imej stereotaip perempuan yang dikenali sebagai gender feminin. Hasil dapatan makalah ini mendapati pengarang novel Seri Dewi Malam telah mengubah fahaman pembaca tentang pengarang lelaki dalam mencitrakan imej perempuan dan menolak stereotaip sedia ada dengan menonjolkan imej positif yang dimiliki oleh watak Rohana sebagai gender feminin yang meruntuhkan stereotaip gender maskulin watak-watak lelaki di dalam novel.
\end{abstract}

Kata kunci: feminis, sistem sosial, konsep gender, stereotaip, maskulin, feminin

Abstract The feminist ideology argues that the production of a creative work amongst male and female author is defined by their specific life and gender experience. Feminists believe that male authors are unable to tap into the 
thoughts and emotional dimension of female authors because they have never experienced the life of a female. This argument emerged as a form of reaction towards the production of novels by male authors who often portray the female characters as 'the second sex', forsaken, tacit and weak in the male dominated social system. Understandably, these prejudiced portrayals reflect their failure in understanding the female gender as a whole. Narrating the female from the male perspective thus has to be approached from the social and cultural context that gives rise to these stereotypes. This paper addresses the notion of gender from the perspective of society and explores the conceptual division between the male representation as 'masculine' and female representation as 'feminine' in the novel Seri Dewi Malam. It argues that the author of the novel has managed to transform the female stereotypes by instilling more positive representations to the protagonist Rohana and her femininity in challenging the masculinity of male characters.

Keywords: Feminism, social system, gender, stereotype, masculinity, femininity

\section{PENGENALAN}

Feminisme adalah gerakan yang memperjuangkan keadilan dan persamaan hak antara perempuan dan lelaki dalam pelbagai bidang. Feminisme muncul daripada rasa ketidakpuasan terhadap sistem sosial dalam masyarakat yang mengakibatkan ketidakadilan gender kerana hak dan peluang besar hanya diberi kepada lelaki. Walhal perempuan juga harus diberi peluang yang sama atas dasar keadilan gender tanpa perbezaan jantina lelaki atau perempuan. Pelbagai usaha dilakukan oleh para feminis dalam usaha mendapatkan hak dan peluang yang sama dengan lelaki, antaranya melalui gerakan persamaan hak 'Equal Rights Movement' dan gerakan pembebasan perempuan 'Women Liberation Movement'. Usaha menuntut keadilan dan persamaan hak ini memunculkan konsep yang mempersoalkan pemahaman sosial dalam masyarakat tanpa mengambil kira perbezaan biologi jantina lelaki dan perempuan. Perbezaan biologi dianggap sebagai sesuatu yang tidak boleh diubah dan bersifat kudrat, sedangkan pemahaman sosiobudaya adalah sesuatu yang dicipta, direka atau dibentuk oleh masyarakat 
yang membolehkannya berubah dan distrukturkan semula. Pemahaman masyarakat telah ditentukan oleh sistem budaya dan struktur sosial sesuatu masyarakat dan masalah gender lahir daripada produk sosial dan budaya. Dari sini, muncul konsep gender yang berasal daripada keinginan untuk menstrukturkan semula hubungan sosial lelaki dan perempuan dalam pergaulan keluarga dan masyarakat untuk menuntut keadilan. Kaitan antara gerakan feminisme dan konsep gender dapat dilihat pada tujuan yang ingin dicapai iaitu mewujudkan keadilan dalam pergaulan keluarga dan masyarakat.

\section{GENDER, STEREOTAIP DAN PATRIARKI}

Perbezaan antara lelaki dan perempuan mengikut konsep gender adalah mengarah kepada perbezaan jenis kelamin yang bersifat biologi. Dalam konteks ini, menurut Humm (2007:177 - 178), jenis kelamin lelaki sering kali dikaitkan dengan gender maskulin, manakala jenis kelamin perempuan dikaitkan dengan gender feminin. Menurut Suzy Suzila, (2006:16 - 17), perkataan gender dibezakan daripada sex untuk menunjukkan perbezaan jantina itu adalah perkara yang diwujudkan budaya sesuatu masyarakat. Orang yang menjadi lelaki atau perempuan telah difahamkan secara sedar atau tidak sedar tentang garis panduan berhubung tingkah laku mereka supaya identiti seksual mereka mantap dan menepati norma-norma budaya sesebuah masyarakat. Secara ringkasnya, istilah jantina merujuk kepada ciri fisiologi dan gender pula merujuk kepada tingkah laku perempuan yang memenuhi sifat-sifat keperempuanan dan tingkah laku lelaki yang memenuhi sifat-sifat kelelakian mengikut tuntutan dan kepercayaan masyarakat. Menurut buku Women's Studies Encyclopedia (1999), gender adalah satu konsep budaya yang digunakan untuk membezakan peranan, tingkah laku, mentaliti, emosi perwatakan di antara lelaki dan perempuan yang berkembang dalam satu kelompok masyarakat. Hal ini merujuk kepada satu pemahaman bahawa identiti, peranan, fungsi, pola, tingkah laku, aktiviti dan persepsi tentang perempuan dan lelaki ditentukan oleh budaya dan masyarakat mereka sendiri. Gender memberi pengaruh yang sangat besar dalam kehidupan seseorang dan mampu menentukan pengalaman yang bakal dilaluinya termasuk menentukan kesihatan, harapan dan kebebasan. 
Gender lelaki dan perempuan berbeza mengikut stereotaip masingmasing. Ia telah lama terpendam dalam psikik masyarakat dan stereotaip ini adalah garis panduan yang dibina oleh masyarakat bagi membezakan ciriciri maskulin lelaki dengan ciri-ciri feminin perempuan. Misalnya menurut Djajanegara (1995:43), lelaki dalam stereotaip masyarakat disifatkan sebagai berdikari, agresif, berdaya saing, memimpin, berorientasi ke luar, penegasan diri, inovasi, disiplin, tenang, aktif, analitis, objektif, berani, tidak sentimental dan sensasi. Perempuan pula disifatkan sebagai bergantung, pasif, lembut, tidak agresif, tidak berdaya saing, subjektif, percaya pada naluri, mudah menyerah, tidak berani mengambil risiko dan emosi. Jika dilihat pada stereotaip yang disebutkan oleh Djajanegara ini, sifat-sifat maskulin dilihat lebih superior dan perempuan berada dalam tingkat yang lebih rendah atau dikenali sebagai inferior, subordinate dan marginalized.

Istilah stereotaip gender sering membawa konotasi negatif, iaitu mewujudkan rasa prejudis terhadap gender yang dianggap sebagai lemah. Stereotaip menyediakan satu sistem untuk mengklasifikasikan lelaki dan perempuan sepanjang hidup serta mempengaruhi harapan diri sendiri, malah penilaian mereka terhadap orang lain (Brannon, 2005:160). Menurut Brannon, stereotaip adalah satu ancaman bagi kumpulan stereotaip yang dikenal pasti sebagai mempunyai stereotaip negatif. Dalam konteks ini, wanita sering distereotaipkan sebagai weak, dependent and timid, whereas men were supposed to be strong, wise and forceful (Brannon, 2005:162). Perkara-perkara stereotaip sebegini adalah satu bentuk ketidakadilan dan penindasan terhadap wanita yang telah berlaku sekian lama, hak-hak perempuan ditindas oleh dominasi lelaki yang menstrukturkan semula budaya dan peranan sosial dengan méletakkan perempuan kepada stereotaip negatif.

Menurut de Beavoir dalam buku The second Sex (1949), lelaki telah membuat wanita menjadi 'the Other' dalam masyarakat kerana wanita diselubungi misteri dan stereotaip seperti itu sentiasa dilakukan oleh masyarakat daripada kumpulan yang lebih tinggi hierarkinya terhadap kumpulan yang lebih rendah. Simon de Beavoir mengatakan wanita dikenali sebagai berada di kedudukan kasta rendah seperti berikut: 
... a caste a group one is born into and cannot move out of. In principle, though, one can transfer from one class to another. If you are woman, you can never become a men. Thus women are genuinely a caste. And the way women are treated in economic, social and political terma makes them into an inferior caste (dalam Schwarzer, 1984:37-38)

Beliau mengatakan penindasan dalam bentuk hierarki ini berlaku juga dalam kategori identiti yang lain seperti bangsa, kelas dan agama. Namun, bagi beliau penindasan hierarki ini lebih ketara kesannya terhadap gender ketika lelaki meletakkan stereotaip tertentu terhadap wanita dan menjadikannya sebagai alasan untuk mewujudkan masyarakat patriarki yang berkuasa mengatur wanita.

Menurut Oxford Advanced Learner's Dictionary, perkataan 'patriarki' merujuk kepada sebuah society, system or country that is ruled or controlled by men (2000:855). Setiap kuasa dalam masyarakat yang menganut sistem patriarki dikawal oleh lelaki. Wanita hanya memiliki sedikit pengaruh dalam masyarakat atau boleh dikatakan tidak memiliki hak atau suara pada lingkungan umum masyarakat. Malah, pekerjaan wanita turut ditetapkan oleh stereotaip masyarakat, iaitu dunia mereka hanya berlegar di sekitar kerja domestik, menguruskan suami, menjadi ibu dan menguruskan anak-anak. Bagi menepati ciri-ciri feminin tersebut, perempuan telah akur dengan 'label' sebagai imej kedua selepas lelaki dan telah tertanam kuat dalam sistem kepercayaan masyarakat. Budaya dan tradisi sangat berkuasa atau sangat berperanan dalam membentuk stereotaip yang mencipta kebergantungan perempuan kepada lelaki. Impak daripada ini, banyak karya sastera awal menampilkan gambaran wanita seperti yang dicirikan dalam masyarakat dan imej wanita menjadi lebih lemah apabila dicitrakan oleh pengarang lelaki yang lahir dan membesar dalam tradisi yang berpegang kepada sistem patriarki. Untuk mengubah fahaman tentang peranan perempuan dalam pergaulan sosial masyarakat, maka konsep gender muncul untuk menstrukturkan semula hubungan lelaki dan perempuan secara universal serta membuka peluang yang setara dalam pelbagai bidang kehidupan tanpa dipengaruhi oleh perbezaan gender. 
Dengan segala penerangan tentang gender lelaki yang mengagungkan stereotaip maskuliniti dan gender wanita yang direndahkan stereotaip feminiti, makalah ini akan melihat bagaimana pengarang novel Seri Dewi Malam (SDM) karya Affifudin Omar mencitrakan imej Rohana dan imejimej lelaki yang terdapat di dalamnya.

\section{SINOPSIS NOVEL}

Mengisahkan percintaan antara Aziz dan Rohana yang berputik di pentas Orkestra Pasar Ria bertempat di Padang Sekolah Melayu Jitra, Kubang Lembu. Encik Fazil adalah ayah Rohana, berketurunan bangsawan, terkenal sangat bengis, berdisiplin dan tidak suka anak-anak gadisnya bercampur dengan orang yang tidak setaraf. Oleh hal yang demikian, hubungan Aziz dan Rohana terjalin secara rahsia dan hanya diketahui oleh ibu dan adik Rohana. Aziz mendapat tawaran ke Sekolah Victoria Institution di Kuala Lumpur setelah mendapat keputusan cemerlang dalam peperiksaan Senior Cambridge. Pemergian Aziz ke Kuala Lumpur telah membuatkan hubungannya dengan Rohana menjadi renggang kerana Rohana sering keluar beriadah bersama Nasir, abang sepupunya. Rohana tidak tahu menahu tentang rancangan Nasir yang ingin memperkenalkannya kepada Syed Munawir, lelaki kaya berumur dalam lingkungan 40-an, sudah mempunyai isteri dan seorang alcoholic.

Nasir bersama isterinya, Mariam dan Syed Munawir merancang untuk menjerat Rohana dengan mencampurkan wiski ke dalam minumannya sehingga membuatkan beliau tidak sedarkan diri ketika menghadiri sambutan hari jadi kecil-kecilan anjuran Nasir di Langkawi. Rohana telah diperkosa Syed Munawir pada malam itu dan keesokannya beliau membuat laporan polis. Akan tetapi, polis menolak kes itu kerana Rohana tidak mempunyai saksi. Tambahan pula, hasil siasatan mendapati persetubuhan itu berlaku atas kerelaan sendiri berdasarkan jawapan yang diperoleh daripada Nasir, Syed Munawir dan Mariam. Encik Fazil meminta Rohana mengahwini Syed Munawir untuk menutup malu diri dan keluarga mereka. Aziz mendapat tahu situasi yang menimpa Rohana dan bertekad untuk mengahwini gadis itu. Mereka berdua bersetuju untuk bernikah di selatan Thailand tanpa pengetahuan ahli keluarga dengan syarat Aziz perlu menurut kehendak 
Rohana yang mahu diceraikan selepas dua minggu bernikah. Penceraian itu dibuat kerana Rohana mahu membalas dendam terhadap perbuatan terkutuk Syed Munawir dengan bersetuju menerimanya sebagai suami.

Rohana berpakat dengan Aziz untuk memasukkan pil estrogen ke dalam minuman Syed Munawir untuk membuatkan nafsu lelakinya menurun. Rohana melancarkan protesnya dengan pelbagai cara ketika menjadi isteri Syed Munawir sehingga akhirnya lelaki itu jatuh sakit, insaf dan meninggal dunia. Sepanjang perkahwinan Rohana, Aziz juga telah mengahwini seorang gadis Padang, Indonesia bernama Shazlin ketika beliau menyambung pengajian ke peringkat Doktor Falsafah di Universiti Cornell, Amerika Syarikat. Walau bagaimanapun, jodoh Aziz tidak panjang kerana Shazlin jatuh sakit dan meninggal dunia kerana mengidap kanser ovari. Rohana dan Aziz akhirnya bersatu sebagai suami isteri yang sah.

\section{ANALISIS MASKULINITI AZIZ YANG DIRUNTUHKAN FEMINITI ROHANA}

Ketertarikan Aziz kepada Rohana bermula pada 'pandangan pertama' di pentas Orkestra Pasar Ria di kampung mereka ketika Rohana dan Zanariah tampil menyanyikan medley lagu-lagu popular. Perasaan cinta pertama dan tertarik pada lawan jenis wajar berlaku pada usia remaja sekitar 15 tahun dan ke atas dan ketika ini Aziz berusia 16 tahun. Tambahan pula, perasaan itu disampaikan dengan bahasa biologi berhubung hormon testosteron dan hormon estrogen yang menghasilkan chemistry yang berupaya mengikat lelaki dan perempuan dalam sebuah perasaan serasi. Namun begitu, pengarang novel ini memberikan ciri-ciri istimewa secara berlebihan kepada watak Rohana sebagai gadis cantik yang cukup sempurna di mata Aziz. Situasi ini digambarkan dengan usaha Aziz untuk tampil menarik di hadapan Rohana setelah gadis itu menerima salam perkenalannya. Misalnya, remaja lelaki ini sanggup mengeluarkan wang simpanannya untuk membeli kasut John White berharga RM40.00, dua helai baju Arrow dan menempah sepasang seluar pantelon berwarna biru kelasi. Semua ini berkat kegigihannya mengambil upah menuai padi dan mengutip buah pinang untuk dikeringkan sebelum dijual (SDM, hlm. 48 - 49). 
Pesona Rohana sangat mempengaruhi Aziz, bukan sahaja dari segi penampilan tetapi juga dari segi pelajaran dan semangat sukan yang tinggi. Bahagian yang dirasai daripada hubungan itu membuatkan Aziz berubah ceria sehingga membuatkan gadis-gadis lain turut tertarik kepadanya atas kecemerlangan akademik dan perubahan fizikal yang tidak lagi selekeh seperti sebelumnya. Pesona Rohana berjaya mengubah sikap dan pendirian lelaki itu daripada seorang lelaki warak, serius, malu dan kekok terutama dengan gadisgadis seusia (2012:61) menjadi lelaki berani walaupun terpaksa berhadapan dengan Encik Fazil, ramah, mudah mesra dan bukan pemalu hanya sematamata untuk mendekati Rohana. Kecantikan Rohana digambarkan pengarang sebagai sangat sempurna di mata Aziz misalnya menerusi petikan berikut:

Bukan sahaja perawakan dan perwatakan Rohana yang merangkul
jiwanya, malah aroma tubuh Rohana sangat-sangat menyenangkannya
walau dalam keadaan apa pun. Walaupun Rohana tidak sempat
bersolek, dengan muka yang sembam dan rambut menggerbang,
namun aura dan aroma jasad Rohana tetap menarik. Sebab itulah
apabila dia mengambil risiko memanjat pagar rumah Rohana pada
pukul 1.00 pagi, di samping membuktikan tiada halangan sebesar
mana baginya mendapatkan Rohana, dia juga hendak melihat Rohana
dalam keadaan demikian (SDM, hlm. 62).

Seterusnya, pengaruh Rohana bukan sahaja dari aspek yang positif kepada Aziz tetapi juga meliputi aspek negatif. Akibat kecantikan yang dimiliki Rohana, Aziz tidak pernah merasa selamat dengan hubungan itu. Beliau diselubungi perasaan cemburu yang berlebihan dan mudah percaya kepada cerita yang disampaikan oleh temantemannya sewaktu berada di Kuala Lumpur.

Hubungan Aziz menjadi tegang apabila isu Rohana kerap keluar bersama Nasir dan Syed Munawir menjadi bualan kawan-kawan Aziz. Kesan negatif daripada itu, Aziz hilang fokus dan gagal mendapat biasiswa Pelan Colombo dan biasiswanya ditukar kepada Biasiswa Persekutuan ke Universiti Malaya (2012:128). Sifat Aziz tidak mencerminkan imej maskulin yang seharusnya kuat dan menjadi tempat kebergantungan perempuan seperti contoh yang disebutkan di atas. Aziz sangat terpikat dengan kecantikan Rohana dan terperangkap dengan perasaan cinta yang menggebu-gebu sehingga melahirkan perasaan sentimental yang berlebihan dan memberi impak negatif terhadap pelajaran dan dirinya. 
Rohana pula boleh dikategorikan sebagai perempuan yang sangat tegas di sebalik kecantikan yang dimilikinya. Beliau serius dengan hubungan yang terbina antara dirinya dan Aziz. Ketegasan yang dimilikinya melebihi pendirian Aziz dan nekad dengan semua tindakannya. Rohana bukan perempuan yang malu-malu menyatakan rasa ingin tahu tentang status hubungannya dengan Aziz setelah mereka tidak berhubung untuk sekian lama. Malah, dia meminta Aziz melafazkan perasaan cinta secara berdepan dengannya untuk membuktikan keikhlasan lelaki itu. Dari bab ini, pembaca dapat mengesan perbezaan watak Rohana dengan watak-watak stereotaip perempuan yang biasanya malu apabila berhadapan dengan lelaki yang dicintai dan lebih pendiam jika berada dalam keadaan sebegini. Rohana ditampilkan dengan sikap ramah, menyenangkan, mendesak dan membalas kata-kata cinta itu secara berdepan. Sikap Rohana yang menguasai perbualan mereka membuatkan Aziz terkejut kerana merasakan gadis tersebut terlalu berterus terang sehingga membuatkan dia sebagai lelaki menjadi 'tergagapgagap cuba mengeluarkan ungkapan keramat' (2012: 21). Bukan hanya itu, watak perempuan ini juga turut mentertawakan sikap malu Aziz untuk menyatakan perasaannya serta menyindir usaha Aziz ketika mereka masih remaja seperti berikut:

"Padan muka Az ... nak sebut perkataan cinta kepada Ana pun takut dan malu. Masa panjat pagar rumah Ana dulu, tak tahu malu dan takut!" (SDM, hlm. 22)

Di sebalik semua keceriaan yang dimiliki Rohana, pengarang menonjolkan sisi dalaman yang lebih tragis pada watak ini. Beliau adalah pejuang keadilan pada dirinya sendiri dan tidak menyerah kalah pada keaiban yang dilakukan oleh Syed Munawir. Beliau memaki hamun Syed Munawir dengan mempersoalkan keturunan lelaki itu sebagai, "Binatang! Sampai hati kau membuat begini kepadaku. Bangsa kurang ajar! Kamu bukan keturunan Nabi Muhammad! Kamu keturunan Syaitan!” (2012:142). Malah, Rohana turut menampar abang sepupunya, Nasir, kerana membiarkan perkara buruk seperti itu berlaku padanya tanpa sedikit pun bertindak sebagai pelindung. Perempuan ini matang dalam mendapatkan keadilannya sebagai mangsa rogol, beliau menunggu untuk membuat pemeriksaan doktor tidak seperti lazimnya kebanyakan mangsa rogol yang jijik dengan hal itu, menangis dan hilang semangat. Rohana tekad membuat laporan ke balai polis dan tidak 
memikirkan tentang malu. Beliau lebih fokus dalam menuntut keadilan dan apabila keadilan itu tidak dapat diperoleh dengan cara yang sepatutnya, beliau nekad untuk membalas dendam.

Rohana tidak gentar untuk berterus terang dengan Aziz tentang perkara yang menimpanya. Sikap ini bukan sifat stereotaip seorang perempuan lemah yang kehilangan kesucian diri. Rohana yakin pada dirinya, nekad dengan tekadnya dan sudah bersedia dengan segala rancangan untuk menjatuhkan Syed Munawir. Dalam suasana tegang begini, pembaca dapat melihat bahawa Aziz lebih beremosi daripada Rohana. Di satu sisi, Rohana memang sedang bersedih dengan nasib yang menimpa dirinya, tetapi di satu sisi lagi Aziz lebih merasai perasaan kecewa itu kerana haknya telah dirampas walhal dia adalah kekasih Rohana dari mereka berusia 15 - 16 tahun lagi. Dalam keadaan emosi benci, marah dan dendam yang membuakbuak, Aziz hadir dengan idea yang tidak rasional seperti “Az mahu Ana jadi isteri Az walau seminit lamanya. Dan Az ada rancangan untuk mengelak tembok sekatan ayah Ana itu" (SDM, hlm. 161). Lebih teruk lagi, pernikahan mereka hanya berlangsung selama dua minggu dan Aziz bersetuju untuk menceraikan Rohana atas alasan "untuk melaksanakan misi menyelamatkan gadis-gadis lain yang tidak berdosa...”(SDM, hlm. 158). Di sini, pembaca mula mempersoalkan tindakan Aziz menceraikan Rohana semata-mata untuk mengizinkan perempuan itu menuntut bela dan demi memuaskan tuntutan itu, seorang suami yang mengaku mencintai isterinya sanggup melepaskan isteri tersebut setelah dua minggu bernikah.

Dari satu aspek, pembaca dapat menilai perwatakan dan kuasa Rohana yang terlalu kuat ke atas diri Aziz. Perempuan ini berupaya mempengaruhi keputusan seorang 'suami' untuk menceraikannya demi mengahwini lelaki yang telah merosakkan isterinya. Aziz terlalu percaya dengan jaminan dan janji Rohana sehingga dia lupa bahawa saingannya adalah seorang 'Syed' yang kaya harta dan wang ringgit. Aziz yakin bahawa Rohana tidak gelap mata dengan semua kemewahan itu. Malah, beliau pasti bahawa rancangan mereka untuk melemahkan nafsu Syed Munawir akan berjaya. Aziz sanggup menurut kemahuan Rohana walaupun beliau terpaksa menanggung derita berpisah dengan wanita yang dicintainya. Jika dilihat dari satu aspek, Aziz berhak untuk menghalang Rohana daripada meneruskan niatnya. Tambahan 
pula, Aziz adalah suami Rohana yang sah setelah mereka bernikah di Masjid Kuala Bara, Wilayah Satun, selatan Thailand. Kuasa cerai atau talak dalam Islam terletak di tangan lelaki sebagai suami dan bukan di tangan perempuan sebagai isteri. Berbeza dengan kisah Aziz dan Rohana, keputusan untuk bercerai itu dipengaruhi oleh rancangan Rohana yang mahukan Aziz menceraikan dirinya setelah dua minggu mereka bernikah. Kuasa dan suara Aziz sebagai suami dinafikan semata-mata untuk menjayakan konspirasi menuntut bela oleh Rohana.

Aziz ditampilkan sebagai seorang lelaki yang lebih menurut kata hati berbanding menggunakan akal rasional. Sikap dominan Rohana terhadap Aziz sebenarnya sangat disedari Aziz dan semuanya menjadi soalan-soalan yang tidak terjawab apabila watak ini sendirian resah memikirkan nasib dirinya.

Kadang-kadang dalam renungan ke atas apa yang sedang berlaku, Aziz memeriksa dirinya dan diri Rohana. Apakah Rohana mendominasikan hidupnya sehingga dia dengan senang bersetuju menerima konspirasi mengkasi Syed Munawir dengan estrogen di mana dia terpaksa membayar harga yang tinggi, iaitu mengorbankan Rohana beberapa waktu menjadi isteri Syed Munawir? Apakah dendam kesumat Rohana terhadap Syed Munawir mengatasi cintanya kepada Aziz? Aziz terfikir adakah hidupnya nanti akan dikuasai oleh segala kehendak Rohana yang ternyata lebih dominan ke atasnya? Bolehkah mereka bahagia bersama nanti, dalam kedudukan kemudi di haluan? (SDM, hlm. 188).

Stereotaip perasaan bimbang, resah, gelisah yang sinonim dengan feminin dapat dikesan dengan banyak pada watak Aziz setelah beliau menerima berita kelahiran anak Rohana bernama Sharifah Fauziah kerana bagi Aziz, Rohana telah memungkiri janji untuk tidak melahirkan anak Syed Munawir. Sikap seperti ini memakan dirinya kerana Syarifah Fauziah adalah anak Aziz dan Rohana hasil 'pernikahan dua minggu'. Walaupun perasaan lelakinya tercabar, watak ini tetap berbelah bahagi antara setia atau terus melupakan janji mereka. Akhirnya, Aziz mengambil keputusan mengahwini Shazlin, gadis Padang yang dikenali dan sama-sama menyambung pengajian di Universiti Cornell, Amerika Syarikat. Keputusan untuk berkahwin dibuat bagi mengelakkan maksiat tetapi jauh di sudut hatinya beliau dirundung rasa gelisah kerana telah memungkiri janjinya kepada Rohana. Berita 
perkahwinan itu disembunyikan daripada pengetahuan Rohana dan hanya disampaikan Aziz setelah kematian Sazlin (SDM, hlm. 311).

Aura dominan Rohana terhadap Aziz dapat dilihat dengan jelas apabila watak ini tidak berani berhadapan dengan Rohana dan mengambil masa yang lama untuk pulang menyelesaikan kemelut mereka. Di sini, imej maskulin Aziz dihancurkan sekali lagi setelah menyaksikan ketabahan wanita itu berjuang sendirian menuntut haknya daripada terus dianiaya. Berikut adalah contoh keterbalikan imej feminin Rohana yang bersifat agresif, keras, berani, tegas, kuat, tidak sentimental, berjaya menjatuh imej maskulin Aziz yang sering diselubungi perasaan bimbang, syak wasangka, emosi, tidak tegas, tidak berani seperti di bawah:

Ketegasan sikap Rohana ini membuat darah Aziz tersirap. Aziz berfikir sejenak, beranikah dia bersemuka dengan Rohana selepas apa yang dilakukannya? Di dalam keadaan takut, Aziz tidak menolak kemungkinan dia terus bermastautin di Amerika sahaja.

(SDM, hlm. 313)

Contohnya ketika Aziz menziarah jenazah Syed Munawir di rumah Rohana:

Apabila dia hendak menjawab soalan Rohana, tiba-tiba dia dilanda emosi, dadanya sebak, air matanya berlinang sehingga dia terpaksa menekan pangkal hidungnya sambil tunduk mengawal perasaan daripada dilihat orang. Kalau tiada orang di sekeliling, dia hendak melutut merangkul lutut Rohana, meminta ampun dan maaf kepadanya atas apa yang dilakukannya, melanggar segala janji mereka dahulu.

Aziz berada dalam keadaan kaku dan hiba berhadapan dengan orang yang dicintainya. Rohana ditinggalkan berjuang seorang diri untuk menuntut bela ke atas suatu kemungkaran besar yang dilakukan terhadap mereka berdua. Dia menunduk sehingga sebaknya hilang, lalu dikeringkan air matanya dengan tisu yang dihulurkan oleh Rohana.

(SDM, hlm. 349) 
Pengarang novel ini melakukan semua hal di atas dengan sengaja, di samping turut mengekalkan imej stereotaip gender feminin, pengarang secara tidak langsung meruntuhkan imej maskulin yang ditampilkan melalui watak Aziz. Imej maskulin yang biasanya unggul dan hak mutlak gender lelaki dikongsi bersama pada watak Rohana melalui tangan seorang pengarang lelaki. Perkara ini mengukuhkan pernyataan yang dibuat oleh Cheng (1999:296) yang berbunyi one should not assume that 'masculine' behaviour is performed only by men, and by all men, while 'feminine' behaviour is performed by women and by all women.

Sifat feminin dan maskulin cenderung mengikut faktor dan situasi gender itu berada dan tidak semua masalah memerlukan wanita bereaksi secara lemah dan penurut. Bahkan, ada waktunya wanita juga boleh bertindak di luar kawalan dan menjadi keras, bergantung pada masalah yang dihadapinya seperti yang tergambar pada watak Rohana.

Jadual 1 Pembalikan imej stereotaip maskuliniti dan feminiti yang berlaku pada watak Aziz dan watak Rohana di dalam novel SDM

\begin{tabular}{|c|c|}
\hline \multicolumn{2}{|c|}{$\begin{array}{c}\text { Imej stereotaip di antara lelaki dan perempuan yang dijelaskan } \\
\text { oleh Djajanegara (1995:43) }\end{array}$} \\
\hline $\begin{array}{c}\text { MASKULINITI } \\
\text { Berdikari } \\
\text { Agresif } \\
\text { Berdaya saing } \\
\text { Memimpin } \\
\text { Berorientasi ke luar } \\
\text { Tegas } \\
\text { Inovatif } \\
\text { Disiplin } \\
\text { Tenang } \\
\text { Aktif } \\
\text { Analitis } \\
\text { Objektif } \\
\text { Berani } \\
\text { Tidak sentimental } \\
\text { Sensasi }\end{array}$ & $\begin{array}{c}\text { FEMINITI } \\
\text { Bergantung/tidak berdikari } \\
\text { Pasif } \\
\text { Lembut } \\
\text { Tidak agresif } \\
\text { Tidak berdaya saing } \\
\text { Subjektif } \\
\text { Percaya pada naluri } \\
\text { Mudah menyerah } \\
\text { Tidak berani mengambil risiko } \\
\text { Emosi }\end{array}$ \\
\hline
\end{tabular}




\begin{tabular}{|c|c|}
\hline \multicolumn{2}{|c|}{ Imej stereotaip yang diterbalikkan dalam novel Seri Dewi Malam } \\
\hline$\underline{\mathbf{A Z I Z}}$ & $\underline{\text { ROHANA }}$ \\
Sentimental & Berdikari \\
Tidak tegas & Berani \\
Tidak berani & Tegas \\
Penurut & Memimpin \\
Tidak tenang & Tidak mudah menyerah \\
Cemburu & Agresif \\
Kuat berimaginasi & Tidak sentimental \\
Tidak rasional & Tenang \\
Mungkir janji & Berdaya saing \\
Bergantung & Berpendirian teguh \\
& Sanggup mengambil risiko \\
\hline
\end{tabular}

\section{KONSPIRASI ROHANA MENJATUHKAN PATRIARKI}

Perbuatan Syed Munawir merogol Rohana dengan bantuan Nasir dan isterinya Mariam adalah satu konspirasi terancang yang sedikit pun tidak memberi ruang kepada Rohana untuk membela diri di muka pengadilan. Syed Munawir, Nasir dan Mariam menafikan tuduhan yang dibuat Rohana dengan menegaskan bahawa perbuatan itu terjadi atas kerelaan hati Rohana sendiri. Maruah perempuan ini dicalarkan lagi dengan penipuan yang mendakwa Rohana sedar dan menyenangi perbuatan mereka bertiga yang mencampurkan wiski ke dalam minuman sehingga menyebabkan dirinya mabuk dan tidak sedarkan diri. Syed Munawir berjaya menolak semua pertuduhan Rohana dengan bantuan Nasir dan Mariam yang sudah gelap mata dengan ganjaran yang bakal diperoleh mereka.

Rohana kekal menjadi mangsa rogol yang tidak dapat menuntut keadilan dan mangsa konspirasi keluarga sendiri kerana beliau tidak dapat mengajukan sebarang saksi yang boleh membuktikan kebenaran laporan polis yang dibuatnya. Perancangan Syed Munawir sangat terancang sehinggakan laporan doktor yang membuktikan terdapat banyak kesan pemerkosaan juga dapat disangkal begitu sahaja. Akibatnya, Rohana diugut bakal dikenakan tindakan undang-undang kerana membuat laporan palsu dan sengaja memfitnah Syed Munawir. 
Rohana tersepit, kehilangan punca dan lazimnya seorang mangsa penindasan sepertinya, dendam adalah cara terbaik untuk membalas semua perbuatan terkutuk itu setelah cara sedia ada gagal membantunya. Di satu sisi, beliau seolah-olah mendapat sokongan padu daripada Aziz tetapi di satu sisi yang lain, Rohana melakukan semua tindakan itu secara bersendirian tanpa bantuan daripada sesiapa termasuk Aziz. Dengan menggunakan segala sifat feminin yang ada pada dirinya, Rohana berjaya meruntuhkan semua sifat maskulin yang ada pada setiap watak lelaki yang memberi pengaruh negatif kepada dirinya. Terdapat tiga watak lelaki yang menggunakan dasar patriarki, sekali gus mempamerkan maskulinitinya ke atas watak Rohana. Watak-watak ini adalah watak Encik Fazil, watak Nasir dan watak Syed Munawir.

\section{i) Watak Encik Fazil, ayah Rohana}

Encik Fazil adalah ayah kandung Rohana dan sebagai seorang bapa kepada sebuah keluarga yang hanya dianggotai oleh perempuan, beliau memegang kuasa patriarki dalam rumah sendiri. Kuasa itu dibesarkan lagi dengan status yang dimiliki oleh keturunan bangsawan yang sering dibanggakan sebagai garis pemisah yang membezakan diri mereka dengan masyarakat bawahan. Oleh itu, beliau acap kali mengingatkan anak-anak perempuannya agar memilih kawan daripada golongan atasan serta sering mengancam anak-anak muda lelaki yang tidak setaraf dengan mereka. Encik Fazil tidak pernah percaya pada kebolehan dan kejayaan yang bakal dicapai oleh Aziz walaupun sedang menyambung pelajarannya di universiti. Biarpun Syed Munawir tidak menghormati Rohana sebagai seorang perempuan dan dirinya sebagai ayah Rohana, beliau lebih sanggup membenarkan anaknya dijadikan isteri kedua kepada seorang lelaki berketurunan Syed yang kaya-raya.

Tindakan Rohana bersetuju dengan hasrat ayahnya yang inginkan dia mengahwini Syed Munawir adalah satu bentuk protes senyap yang dirancang dengan teliti. Kepatuhan Rohana untuk menjadi isteri kepada orang yang telah merogolnya berjaya membuka mata Encik Fazil bahawa perhitungan yang dibuat demi kebaikan Rohana adalah satu perhitungan yang salah. Ego Encik Fazil berjaya dipatahkan oleh ketaatan Rohana sebagai anak 
yang menurut kata ayahnya walaupun terpaksa menjadi mangsa keganasan suami tersebut. Kuasa patriarki itu runtuh melalui dialog yang diucapkan oleh Hamidah, ibu Rohana kepada Encik Fazil setelah mereka bertandang ke rumah Rohana seperti berikut:

Hamidah menempelak suaminya, "Itulah abang, hendak sangat kepada orang bangsawan. Akibatnya anak kita yang menanggung seksaan!"

"Aku hanya hendak menyelamatkan Rohana dan kita daripada malu sahaja. Tak kusangka Syed ini seorang yang ganas!"

"Takkan abang tak tahu orang yang merogol orang adalah jenis manusia yang ganas!" ujar Hamidah. "Manalah aku tahu!" jawab Encik Fazil.

"Dulu saya suruh Rohana kahwin sahaja dengan Aziz tu, abang tak benarkan!" tempelak Hamidah lagi. "Kamu hendak anak kita makan pasir?" jawab Encik Fazil, keras suaranya.

"Lebih baik makan pasir daripada menelan air mata." Hamidah terus melawan. Encik Fazil membisu, mengalah (SDM, hlm. 177).

ii) Watak Nasir, abang sepupu Rohana

Seterusnya, watak Nasir, abang sepupu Rohana yang seharusnya menjadi pelindung kepada adik sepupunya merupakan manusia yang suka mengambil peluang dan menjadikan Rohana sebagai 'umpan' untuk mencapai matlamat demi kepentingan sendiri. Rancangan demi rancangan diatur Nasir bersama Syed Munawir. Antaranya meminta Rohana agar bermalam di bilik hotel bernombor 612 bersama Syed Munawir ketika mereka pergi ke Pulau Pinang untuk membeli-belah. Nasir mempergunakan kepercayaan Pak Langnya, iaitu ayah Rohana dengan mengatur rancangan, sesuai dengan kehendak Syed Munawir. Rohana mempertahankan dirinya dan mempersoalkan kedudukan Nasir sebagai abangnya seperti berikut:

"Ana tidak mahu tidur sebilik dengannya walaupun dia berjanji tidak apa-apakan Ana. Salah perbuatan itu, abang!" Rohana membantah keras.

“Abang pasti dia tidak akan kacau Ana," pujuk Nasir lagi.

"Ana kata tak mahu, tak mahu lah, abang. Apa! Abang mahu mempersundalkan Ana ke? Kan Ana ini adik abang? Rohana mula naik berang, air matanya mengalir ke pipi (SDM, hlm. 17). 
Rohana mempunyai sifat yang tegas dalam hal-hal mempertahankan dirinya daripada menjadi mangsa lelaki. Watak ini lantang menyuarakan hasratnya jika perkara itu bertentangan dengan norma masyarakat. Rohana adalah watak yang tahu menjaga diri dan sedar dengan siapa beliau berkawan. Beliau hanya keluar bersama Aziz kerana lelaki itu adalah kekasihnya dan Nasir kerana lelaki itu adalah sepupunya yang dianggap seperti abang sendiri. Tuduhan kawan-kawan rapat Aziz yang mengatakan Rohana tidak setia dan sering keluar dengan lelaki lain adalah kerana mereka tidak mengetahui hubungan keluarga antara Nasir dan Rohana. Sebagai seorang abang, Nasir tidak menjalankan tanggungjawab yang sepatutnya, malah berusaha untuk menjayakan rancangan Syed Munawir sehingga merosakkan darah daging sendiri. Nasir bersepakat dengan isterinya menutup kejadian rogol yang menimpa Rohana dan meletakkan Rohana di posisi orang yang bersalah kerana membuat tuduhan palsu. Nasir dan Mariam akhirnya meninggal dalam kemalangan ngeri di Gurun, Kedah (2012:202). Sebelum meninggal, Nasir sempat memohon maaf kepada Rohana dan Aziz kerana telah memisahkan mereka. Rohana sekali lagi membuktikan bahawa feminiti yang dimilikinya mampu menyedarkan seseorang terhadap kesalahan yang dilakukan. Biarpun Nasir telah menjadi penyumbang terbesar yang menghancurkan hidupnya, Rohana tetap prihatin terhadap nasib ketiga-tiga anak Nasir dan Mariam yang terselamat daripada kemalangan tersebut. Sifat pemaaf dan berperikemanusiaan ini membuktikan bahawa Rohana adalah perempuan yang berhati mulia.

\section{iii) Watak Syed Munawir, suami Rohana}

Watak lelaki ketiga yang menggunakan kuasa patriarkinya terhadap Rohana adalah watak Syed Munawir yang berjaya mengahwini Rohana cara paksa. Pemaksaan dalam erti kata merogol dan demi menutup malu diri serta keluarga. Syed Munawir tidak mampu melawan nafsunya yang terpikat pada kecantikan yang dimiliki Rohana dan sanggup melakukan pelbagai cara untuk menjadikan perempuan itu sebagai isterinya. Melalui watak Syed Munawir ini, sikap protes dan sifat feminin Rohana menyerlah serta berjaya meruntuhkan semua sifat maskulin yang dimiliki sang suami. Berikut adalah rentetan peristiwa yang membuktikan Rohana melakukan konspirasi terancang untuk membalas dendam perbuatan terkutuk Syed 
Munawir terhadap dirinya.

Jadual 2 Rentetan konspirasi Rohana untuk membalas dendam terhadap Syed Munawir bermula dari protes yang bersifat agresif sehingga protes yang lebih bersifat tenang.

\begin{tabular}{|c|c|}
\hline Bil. & $\begin{array}{c}\text { Rentetan konspirasi Rohana untuk membalas } \\
\text { dendam terhadap Syed Munawir }\end{array}$ \\
\hline 1 & $\begin{array}{l}\text { Berkahwin dengan Aziz di Kuala Bara, Wilayah Satun, selatan Thailand tanpa } \\
\text { pengetahuan sesiapa termasuk ahli keluarga mereka (SDM, hlm. 150). Bercerai } \\
\text { talak satu dengan Aziz setelah dua minggu pernikahan mereka untuk membolehkan } \\
\text { Rohana menikahi Syed Munawir dan melaksanakan misinya (SDM, hlm. 158). }\end{array}$ \\
\hline 2 & $\begin{array}{l}\text { Enam minggu setelah perceraiannya dengan Aziz, Syed Munawir mengahwini } \\
\text { Rohana. Beliau dilimpahi kemewahan dan Rohana mengambil kesempatan dengan } \\
\text { berbelanja sebanyak-banyaknya. Rohana menjalankan tanggungjawabnya sebagai } \\
\text { seorang isteri yang pasif di tempat tidur sehingga membuatkan Syed Munawir } \\
\text { terpaksa mencari 'makan luar' (SDM, hlm. 170) }\end{array}$ \\
\hline 3 & $\begin{array}{l}\text { Rohana tidak lupa kepada misinya untuk mencampurkan pil-pil estrogen ke } \\
\text { dalam kopi Syed Munawir setiap pagi (2012:171). Pil-pil itu akan memberi kesan } \\
\text { berlawan terhadap ciri-ciri maskulin seorang lelaki kerana pil estrogen membekal } \\
\text { hormon wanita seperti yang dijelaskan berikut: } \\
\text { Akan tetapi. Jika seseorang lelaki itu diberi makan } \\
\text { pil estrogen, maka segala sifat betina akan muncul } \\
\text { pada dirinya, seperti buah dadanya akan membesar } \\
\text { dan menonjol, alat kelaminnya akan mengecil } \\
\text { dan tidak berdaya tegang, serta nafsu syahwat } \\
\text { kejantanannya menurun (SDM, hlm. 157). }\end{array}$ \\
\hline 4 & $\begin{array}{l}\text { Rohana secara terang terangan mempamerkan kemewahan yang dimilikinya } \\
\text { dengan memandu kereta sport dan membeli belah di sekitar Alor Setar. Beliau } \\
\text { bebas bergerak ke sana sini tanpa mempedulikan urusan rumah yang diserahkan } \\
\text { bulat-bulat kepada pembantu (SDM, hlm. 171). }\end{array}$ \\
\hline 5 & $\begin{array}{l}\text { Rohana digelar 'kaduk baru jumpa junjung' kerana hanya membahasakan dirinya } \\
\text { sebagai 'saya' atau 'I' pada golongan bangsawan seperti Syed atau Tengku (SDM, } \\
\text { hlm. 172). }\end{array}$ \\
\hline 6 & $\begin{array}{l}\text { Rohana menyemarakkan lagi perasaan benci kaum kerabat Syed Munawir yang } \\
\text { bertandang ke rumahnya dengan mengunci diri di dalam bilik tidur sambil } \\
\text { mendengar muzik atau memandu kereta sportnya ke Jitra atau Sungai Petani } \\
\text { untuk berjumpa kawan-kawan lama (SDM, hlm. 172). }\end{array}$ \\
\hline
\end{tabular}




\begin{tabular}{|c|c|}
\hline 7 & $\begin{array}{l}\text { Syed Munawir tidak mempedulikan aduan mengenai sikap Rohana. Baginya Rohana } \\
\text { adalah aset sosial yang sangat berguna untuk meningkatkan ego dan memperagakan } \\
\text { Rohana, Ratu Kebaya Kedah sebagai isterinya (SDM, hlm. 172). }\end{array}$ \\
\hline 8 & $\begin{array}{l}\text { Rohana hamil setelah dua minggu berkahwin dengan Syed Munawir. Beliau } \\
\text { melahirkan anak perempuan yang diberi nama Sharifah Fauziah. Dengan } \\
\text { kelahiran bayi ini Rohana mengatur strategi baru dengan memasukkan katil } \\
\text { bayi ke bilik tidur sehingga membuatkan Syed Munawir berpindah ke bilik lain } \\
\text { kerana terganggu dengan tangisan bayi. Rohana juga hanya memanggil anaknya } \\
\text { dengan nama Fauziah sahaja dan mengarahkan semua pembantu rumah mereka } \\
\text { melakukan hal yang sama. Ini merupakan satu usaha untuk menggugurkan gelaran } \\
\text { 'Sharifah' (SDM, hlm. 174-179). }\end{array}$ \\
\hline 9 & $\begin{array}{l}\text { Syed Munawir terdesak mencari 'makan luar' dan tidak memilih orang atau } \\
\text { tempat untuk memuaskan nafsunya. Beliau mendapatkan khidmat khunsa dengan } \\
\text { harga yang murah di sekitar Stesen Kereta api Alor Setar selepas jam } 12 \text { malam } \\
\text { (2012:178). Syed Munawir diserang strok dan penyakit kelamin jenis herpes } \\
\text { sehingga terpaksa dimasukkan ke hospital (SDM, hlm. 180). }\end{array}$ \\
\hline 10 & $\begin{array}{l}\text { Protes Rohana semakin giat setelah mengetahui suaminya mengidap penyakit } \\
\text { kelamin, beliau meminta agar mereka tidak lagi berkongsi bilik tidur, bilik air, } \\
\text { tuala dan hubungan seksual mereka terputus (SDM, hlm. 180). }\end{array}$ \\
\hline 11 & $\begin{array}{l}\text { Rohana mengambil alih tugas mengawas ladang getah Syed Munawir seluas } \\
800 \text { hektar. Rohana berjaya menukar milik tanah secara mutlak ke atas namanya } \\
\text { dengan bantuan ayahnya sebagai kerani besar di Pejabat Daerah Jitra. Beliau } \\
\text { menumpahkan perhatian kepada urusan ladang yang mampu memberi pendapatan } \\
\text { bersih sebanyak RM240 ribu setiap bulan dan pendapatan itu mampu menyara } \\
\text { kehidupannya dan Fauziah sekali gus menyelamatkan suaminya dari kemiskinan } \\
\text { (SDM, hlm. } 181-182 \text { ). }\end{array}$ \\
\hline 12 & $\begin{array}{l}\text { Rohana menjalankan tanggungjawabnya menjaga suami yang terlantar } \\
\text { sakit dengan meluangkan masa berbual dan berulang alik ke hospital untuk } \\
\text { mendapatkan suntikan antibiotik. Jiwa Rohana menjadi lebih tenang dengan } \\
\text { merawat suaminya (SDM, hlm. } 185 \text { - 186). }\end{array}$ \\
\hline 13 & $\begin{array}{l}\text { Ketika Syed Munawir sudah mula insaf, Rohana gembira dengan perubahan itu. } \\
\text { Rohana merasakan dendamnya terbalas dan Syed Munawir sudah berubah menjadi } \\
\text { manusia baik, tetapi Rohana tidak pernah melupakan tekadnya untuk kembali } \\
\text { semula kepada Aziz dan beliau sentiasa berdoa kepada Allah agar rancangan itu } \\
\text { berjaya (SDM, hlm. 231). }\end{array}$ \\
\hline 14 & $\begin{array}{l}\text { Syed Munawir semakin uzur, Rohana mengambil posisi sebagai 'bos' di rumah } \\
\text { mereka tetapi tetap sahaja memastikan keperluan dan tugasnya sebagai isteri dan } \\
\text { ibu terlaksana dengan baik. Rohana berusaha mengukuhkan kewangan dengan } \\
\text { melaburkan wang untung ladang ke pasaran saham (SDM, hlm. 259). }\end{array}$ \\
\hline
\end{tabular}




\begin{tabular}{|c|l|}
\hline 15 & $\begin{array}{l}\text { Syed Munawir sembuh dari simptom withdrawal (sawan) alkohol dengan } \\
\text { mengikuti program Innabah, beliau sendiri memecahkan botol-botol arak di bilik } \\
\text { simpanan khasnya dan Rohana menyamak bilik itu untuk dijadikan sebagai bilik } \\
\text { solat (SDM, hlm. 283). Syed Munawir berkawan dengan mereka yang soleh sahaja } \\
\text { seperti Tengku Rusdi dan Khalid. }\end{array}$ \\
\hline 16 & $\begin{array}{l}\text { Keadaan kesihatan Syed Munawir semakin menurun, beliau memohon maaf } \\
\text { kepada Rohana di atas kesilapannya dan Rohana juga turut menceritakan semua } \\
\text { kesilapannya termasuk konspirasi membalas dendam yang dirancangnya (SDM, } \\
\text { hlm. 301 - 302). }\end{array}$ \\
\hline 17 & $\begin{array}{l}\text { Rohana membantu Syed Munawir membuat sedekah kepada fakir miskin dan } \\
\text { membina masjid baru di Kampung Kubang Palas (SDM, hlm. 318). }\end{array}$ \\
\hline 18 & $\begin{array}{l}\text { Harta Syed Munawir yang sudah bertukar hak kepada Rohana dibahagikan } \\
\text { kepada anak-anak bekas isteri pertama di Kelantan dan Sharifah Fauziah tanpa } \\
\text { keuntungan di pihaknya (SDM, hlm. 334). }\end{array}$ \\
\hline 19 & $\begin{array}{l}\text { Syed Munawir mempertahankan Rohana di hadapan kakaknya Sharifah Maheran } \\
\text { yang memaki hamun Rohana kerana telah melarangnya untuk minum arak di } \\
\text { rumah mereka. Dialog tersebut berbunyi seperti berikut: } \\
\text { "Ya kak, saya mengikut Rohana yang menunjukkan } \\
\text { kepada saya jalan ke syurga! Saya tidak paksa } \\
\text { kakak ikut saya, tetapi jangan ajak saya ikut kakak } \\
\text { menuju ke neraka!" (SDM, hlm. 337) }\end{array}$ \\
\hline $\begin{array}{l}\text { Rohana sentiasa menyembunyikan rahsia perkahwinannya dengan Aziz dan siapa } \\
\text { sebenarnya Sharifah Fauziah kepada Aziz dan Syed Munawir (SDM, hlm. 340). }\end{array}$ \\
\hline
\end{tabular}

Pengarang bersikap adil kepada watak Rohana dengan tidak menghitamkan watak ini dengan sifat-sifat negatif stereotaipnya. Watak Rohana diunggulkan oleh pengarang melalui sifat positif feminitinya iaitu penyabar, pemaaf, prihatin dan menjalankan tanggungjawabnya sebagai isteri dengan menjaga kebajikan suaminya dari segi kesihatan dan harta benda. Sifat positif ini terbukti meruntuhkan tembok kuasa patriarki yang dikuasai oleh Encik Fazil, ayahnya dan Syed Munawir, suaminya sehingga membuatkan mereka insaf atas kesilapan menganiaya watak Rohana dengan kekerasan dan pemaksaan. Ketabahan dan kegigihan Rohana mengubah Syed Munawir menjadi seorang manusia yang baik, bermula dengan kebencian yang tinggi dan berubah menjadi ikhlas dalam perjuangannya menyelamatkan suami daripada terus diselubungi dosa. 


\section{KESIMPULAN}

Pengarang novel ini mempunyai keupayaan untuk menulis daripada perspektif perempuan walaupun tidak terlalu mendalam dari aspek dimensi kejiwaan perempuan. Hal ini boleh kita lihat pada peristiwa Syed Munawir merogol Rohana. Pengarang berjaya membuatkan pembaca merasai perasaan benci, rasa dendam dan tertekan atas perlakuan tersebut seperti mana yang dilontarkan oleh watak Rohana yang mengatakan "Tubuh ini telah menjadi barang rompakannya!” (2012:160). Perasaan nekad untuk membalas dendam, rasa dirampas serta jijik terhadap perlakuan buruk Syed Munawir dikuatkan lagi dengan protes demi protes yang dilakukan oleh Rohana membuktikan pengarang berupaya menampilkan perasaan perempuan yang teragut kesuciannya dan boleh disimpulkan sebagai berjaya dari aspek tersebut. Namun, hal yang lebih menarik adalah pengarang novel ini telah menterbalikkan stereotaip gender feminin yang dikenali sebagai lemah, bergantung, penurut, patuh, pasif, tidak berani, tidak berdaya saing kepada watak perempuan yang dominan dan sanggup mengambil risiko, sekali gus meruntuhkan stereotaip maskulin yang sekian lama tertanam dalam diri kita sebagai kuat, tidak sentimental, tegas, tenang, disiplin, memimpin, aktif dan sebagainya.

Maskuliniti Aziz diruntuhkan apabila watak ini berhadapan dengan Rohana, perempuan yang dicintainya dan Aziz digambarkan sebagai lelaki yang sangat memerlukan perempuan (Rohana dan Shazlin) sebagai pendamping untuk memberi semangat dan mencipta kejayaan. Dari satu sisi, hal tersebut menampilkan kebergantungan watak Aziz kepada perempuan serta kebolehan watak perempuan mengatur, mengawal dan mempengaruhi setiap keputusan yang dilakukan Aziz. Selain itu, stereotaip maskulin yang sinonim dengan sistem patriarki seperti yang tergambar pada watak Encil Fazil, Nasir dan Syed Munawir berjaya dilenyapkan oleh semua stereotaip gender feminin watak Rohana, sama ada positif mahupun negatif. Seri Dewi Malam mencitrakan kisah cinta yang menarik, konflik sebab akibat yang dramatik, dan pengakhiran yang berbeza daripada novel popular yang berada di pasaran. Jika dilihat dari segi bahasa, ia agak berbeza dengan bahasa novel popular kontemporari kerana penggunaan ayat lama yang terdapat di 
dalamnya. Tetapi jika dinilai dari segi naratif dan aspek dramaturgi, novel ini mempunyai cerita yang kuat untuk dijadikan sebuah drama rantaian di televisyen, di samping menampilkan konflik-konflik besar melibatkan dendam seorang isteri dan bekas suami yang tersepit di antara janji-setia dan percaya.

\section{RUJUKAN}

Affifudin Omar. (2012). Seri Dewi Malam. Kuala Lumpur: Dewan Bahasa dan Pustaka.

Brannon, Linda. (2005). Gender: Psychological perspectives. (Edisi keempat). Boston: Pearson.

Cheng, C. (1999). Marginalised masculinities and hegemonic masculinity: An introduction. Journal of Men's Studies, 7(3), pp. 295 - 310.

Djajanegara, Soenarjati. (1995). Citra wanita dalam lima novel terbaik Sinclair Lewis dan gerakan wanita di Amerika. Depok: Universitas Indonesia.

Humm, Maggie. (1986). Feminist criticism. Great Britain: The Harvester Press.

Nicholson, Linda J. (1995). Feminism/Postmodernism. New York and London: Routledge.

Ruzy Suzila Hashim. (2006). "Meniti duri dan ranjau: Pembikinan gender dan seksualiti dalam konteks dunia Melayu." SARI: Jurnal Alam dan Tamadun Melayu 24. Halaman 15 - 34.

Schwarzer, A. (1984). After the second Sex: Conversations with Simone de Beauvoir (Terj.). New York: Pantheon Books.

Tierney, Helen. (1999). Women's studies encyclopedia. USA: Greenwood Press. 